Registrar-General, the incidence of death from angina pectoris after 60 years of age declines year by year until at 80 it approaches nullity, whereas during the same age periods among the general public the incidence of coronary disease is increasing year by year until it reaches universality. ${ }^{9}$

Sir Douglas Powell observes that the fact of præcordial pain appearing after marked exertion is suggestive of aortic disease. But permit me, Sir, to point out to you that muscular effort excites paroxysms in a class of cases which boast for their pathology the segmentary neuroses. I refer to the class of paroxysmal spasmodic complaints associated with the musculature of the alimentary canal and other abdominal visceral cavities. Included in this class are: trismus of tetanus, palato-pharyngeal spasm of hydrophobia, œsophagismus, gastrismus, enterospasm, biliary and renal colic, colismus, tenesmus, strangury and utero-spasm; paroxysms in all these instances alike are induced or aggravated by muscular effort. I may also add in this connexion that the spasm in certain of these disorders is reduced, as in the angina pectoris, by administrations of nitro-glycerine.

If the angina pectoris be included in this class of paroxysmal spasmodic disorders, as suggested by Heberden, a rational explanation is furnished for every symptom of the complaint and for every phase of it.-I am, Sir, yours faithfully,

Streatham Hill, May 4th, 1915.

H. WALTER VERDON.

\section{THE MEDICAL PROFESSION AND THE NEEDS OF THE ARMY.}

\section{To the Editor of THE LANCET.}

SIR,-May I be allowed some space in your columns to suggest to your readers, including those in authority, a few points as to why there exists dissatisfaction among medical men who have already given their services to the army, and also why some who have not yet joined are hanging back from so doing.

The leading article in THE LANCET of May 8th puts the case of the War Office plainly and judicially, but from what I gather from those who are serving as medical officers in the Territorial Forces the causes of dissatisfaction are other than those to which you refer.

I can rouch for the following matters:Grievances settle round two points, pay and promotion, not so much per se but as regards the inequality between the Territorial Forces and the forces popularly known as Kitchener's Army. A lieutenant in the R.A.M.C. (Territorial) gets 14s.per diem, together with 3 s. for billet and 1s. $9 d$. per diem for rations. A lieutenant in "Kitchener's Army" gets $£ 14 s$. per diem and $£ 60$ on release from service. Promotion, too, is slow; I know of at least one instance in which an officer was gazetted some seren months ago, he is still a lieutenant, although he has been doing a major's work (in command of a section) all the winter and spring. A recent application for promotion, backed by his commanding officer, was refused on the ground that by the Territorial Forces Regulations a lieutenant R.A.M.C. must have seen at least three years' service. Other executive branches of the service get rapid promotion; for instance, a man who was gazetted second lieutenant in October, 1914, in the Army Service Corps is now a captain.

9 American Journal of the Medical Sciences, May, 1906.
The Territorial R.A.M.C. men only joined originally for home service, but an Army Order has been made insisting on service anywhere required, whether abroad on active service or in India; and it must be remembered that Territorial R.A.M.C. are frequently almost all elderly men, for the younger men naturally join Kitchener's Army. The question of pay is not the only griev. ance. The question of promotion is felt to rankle, for the refusal of it seems to show a grudging recognition of the spirit which led elderly practitioners to volunteer, and which the War. Office would do well to foster rather than, as it is doing, to dash.

$$
\begin{aligned}
& \text { I am, Sir, yours faithfully, } \\
& \text { May 11th, } 1915 .
\end{aligned}
$$$$
\text { To the Editor of THE LANCET. }
$$

SIR,-Many eligible men still abstain from giving up lucrative practices and offering their services for the following reasons:-

1. All medical officers, though their work and risks may be identical, are not treated alike. Treatment depends on whether a man is: (a) a temporary Royal Army Medical, in which case he receives the rank of lieutenant but the pay of 25s. a day (major's pay) ; (b) a permanent Royal Army Medical, in which case he receives the rank of captain and draws captain's pay; or (c) a Territorial Royal Army Medical, in which case he receives the rank and pay of lieutenant (14s. a day pay and $4 s .9 d$. allowances at times). The Territorial medical officer has almost in. variably made bigger sacrifices, yet receives the least pay.

2. Certain medical officers acting in a combatant. capacity have offered to transfer to the R.A.M.C. and have not been permitted to. (Their applications have not even been forwarded.)

3. Many R.A.M.C., both Regulars, Temporary, and Territorial, have for months past been kept at home only partially employed when they have repeatedly asked to be allowed to go abroad, their work being carried on at home by civilian doctors. Is it not reasonable for them to ask themselves whether the War Office can really be so very short, as it does not appear to make the best use of what material it already has at its disposal.

I suggest the following as a remedy: 1. Do away with the arbitrary distinction between Territorial and Regular. Classify, if necessary, into home and imperial service medical officers, but let all army doctors come under the same departmental control and let them all receive the same scale of pay. 2. As it takes approximately five months to train a com. batant officer, but five years to train a medical officer, let all doctors at present serving in a com. batant capacity revert to their professional work. 3. Do away with the medical officer for regimental work at home and substitute the part-time civilian practitioner, who could, without much heavier work, see the 20-30 army at the same time as he sees his panel patients. And lastly, if it were found that the Admiralty have a surplus of medical officers, could no amicable arrangement be arrived at whereby either a united medical service could be formed or even a united medical reserve service on which either could draw as requirements arose?

I am, Sir, yours faithfully,

May 7th, 1915.

LIEUtenanT R.A.M.C.(T.F.). 